表 5 尿素誘導体 の 性 質

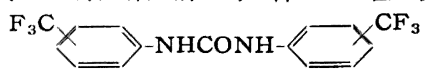

置換位罚

融点 $\left({ }^{\circ} \mathrm{C}\right)$

189 190

$194 \sim 195$

209 210 (分解)

$\mathrm{N}$ 分析值 $(\%)$

$o_{0} o^{\prime}-\left(\mathrm{CF}_{3}\right)_{2}$
$m, m^{\prime}-\left(\mathrm{CF}_{3}\right)_{2}$

$p, p^{\prime}\left(\mathrm{CF}_{3}\right)_{2}$

$*$ ( ) 内は勫筧値

近に $\nu_{\mathrm{NCO}}$ の, $1320 \mathrm{~cm}^{-1}, 1180 \mathrm{~cm}^{-1}$ および $1130 \mathrm{~cm}^{-1}$ 付近に $\nu_{\mathrm{Cr}_{3}}$ の強い吸収を示す。p-体のスペクトルを図 1 に示す。また イソシアナートに少量の水を添加して放置すれば, 対応する尿素 誘導体 $3^{3}$ に変化する。これらの性質を表 5 に示す。

\section{3 実験}

\section{$3 \cdot 1$ シアノベンゾトリフルオリドの合成}

$o-, m$ - または $p$-ブロムベンゾトリフルオリド $22.5 \mathrm{~g}(0.1$ $\mathrm{mol})$, シアン化銅（Ｉ） $10.5 \mathrm{~g}(0.12 \mathrm{~mol})$ をジメチルホルムアミ ト $15 \mathrm{ml}$ k加光，6時間加熱反応させる。反応後塩化鉄 (III) 40 $\mathrm{g}$, 濃塩酸 $10 \mathrm{~m} l$, 水 $60 \mathrm{ml}$ の溶液中に注加し, $60 \sim 70^{\circ} \mathrm{C}$ に 20 分 間加温して油層を分離させる。次いで油層を $2 \%$ 塩酸， $2 \%$ 水酸 化ナトリウム水溶液, 扣よび水で順次洗浄し, 乾燥後減圧分留す る。

\section{$3 \cdot 2$ トリフルオルメチル安息香酸}

3·2・1 m-, $p$-トリフルオルメチル安息香酸 対応するシアノ ベンゾトリフルオリド $17.1 \mathrm{~g}(0.1 \mathrm{~mol})$ を濃塩酸 $25 \mathrm{ml}$, 氷酢酸 $17 \mathrm{~m} l$ の混合液に加え，10 時間加熱反応させる。反応後 $100 \mathrm{~m} l$ の水中に注加し，析出物をこしわける。次いで

※3 $o$ - 体の場合は少量のアミンが検出されたが, $m-, p$-体に 拈いては検出されなかった。一般に陰性置換基の入ったフ エニルイソシアナートは水との反応により, アミンと尿素 誘導体の混合物を生成するが ${ }^{15)}$ ，本実験では 0 -体におい てのみアミンの生成が認められた。

15) R. G. Arnold, J. A. Nelson, J. J. Verbanc, Chem. Revs. 57, 46 (1957).
タノールより， p- 体は石油ペンジン 9: ィタノール1の溶媒より 再結晶する。

$3 \cdot 2 \cdot 20$-トリフルオルメチル安息香酸 0 -シアノベンゾトリ フルオリド $17.1 \mathrm{~g}(0.1 \mathrm{~mol})$, 濃塩酸 $25 \mathrm{ml}$, 氷酢酸 $17 \mathrm{ml}$ をガラ ス製耐圧ビンに入れ，ときどきふりませながら 135〜 $145^{\circ} \mathrm{C}$ の油 浴中で 12 時間加熱する。後処理は $3 \cdot 2 \cdot 1$ と同様に行ない, 析出 物を石油ベンジンより再結晶する。

\section{$3 \cdot 3$ トリフルオルメチルヘンンソイルクロリト}

$o-, m$ または $p$-トリフルオルメチル安息香酸 $19.0 \mathrm{~g}(0.1 \mathrm{~mol})$ にチオニルクロリド $28.5 \mathrm{~g}$ を加え， 2 時間加熱する。反応後減 圧下でチオニルクロリドを留去し，残留液を減圧分留する。

\section{4 トリフルオルメチルフェニルイソシアナートの合成}

$3.4 \cdot 1$ 湿式法 $m$-トリフルオルメチルベンゾイルクロリド $10.5 \mathrm{~g}(0.05 \mathrm{~mol})$ をアセトン $100 \mathrm{ml}$ に溶解し， 5～10C でかき まぜながらアジ化ナトリウム $3.5 \mathrm{~g}(0.055 \mathrm{~mol})$ を水 $12 \mathrm{ml}$ に溶 かした溶液を滴下し，さらに 15 分間かさまぜたのち氷水を加え る。反応液をエーテル抽出し, エーテル層を水洗, 乾燥する。エ 一テル留去後の酸アジドの油分を金属ナトリウムで脱水したベン ゼン $15 \mathrm{ml}$ に加光, 2.5 時間加熱反応させる。反応後ベンゼンを 留去し, 减圧分留する。

3.4-2 乾式法 $0-, m$ - またはp-トリフルオルメチルベンッ゙ イルクロリド $10.5 \mathrm{~g}(0.05 \mathrm{~mol})$, アジ化ナトリウム $3.5 \mathrm{~g}(0.055$ $\mathrm{mol})$ を脱水精製したベンゼン $50 \mathrm{ml}$ に加党，かきまぜながら 13 時間加熱反応させる。反応後不溶物をこしわけ, ペンゼンを留去 後減圧分留する。

\section{5 尿素誘導体の合成}

$o-, m$ - たは $p$-トリフルオルメチルフェニルイソシアナート $0.54 \mathrm{~g}(0.03 \mathrm{~mol})$, 水 $0.1 \mathrm{ml}$ を混合し, 室温で 2 日間放置する と白色固体が生成する。これをこしわけ 50〜80\%エタノールよ り再結晶する。

（昭和 38 年 4 月 3 日，日化第 16 年会講演）

\title{
ショ 糖脂肪酸モノエステルの液-液抽出法による分離†
}

\author{
(昭 和 38 年 8 月 1 日 受 理)
}

\section{大竹 俊 樹 - 玉手英四郎*}

\begin{abstract}
ショ糖脂肪酸エステル混合物をnーヘキサン，八ロゲン化炭化水素，メタノール，拉よび水からなる2液相系にて分配 させると，モノェステルの大部分は極性層に移行し，この操作をくりかえすことにより，泣以上のポリェステルをほとん ど含をない試料を調製することができる。極性層の一部を濃縮乾固して，非ショ楉エステル性の不純物を除去した後， 二,三の物性を㭘討した。
\end{abstract}

\section{1 緒 言}

$N, N^{\prime}$-ジメチルホルムアミド (DMF) 中にてアルカリ触媒の存 在下, ショ糖と脂肪酸メチルのエステル交換反応により生成させ

$\dagger$ 本報を「ショ糖脂肪酸エステルの分別に関する研究（第 1 報)」とする。

* 大日本製糖株式会社中央研究所 : 横浜市神奈川区守屋町.
たショ糖エステル※1 はモノ，ジ,トリエステル等各種エステル 価を有する物質の混合物である。ショ糖ェステルのェステル価別 分別について，著者1)，R．U. Lemieuxs ら²执よび美間ら

※1 以下ショ糖エステルとはショ糖脂肪酸エステルの略である。

1) 大竹，精糖技術研究会誌，第 12 号，25３4 (1963).

2) R. U. Lemieux, A. G. McInnes, Can. J. Chem, 40, 2376 2392 (1962).

3）美間，北森，神沢，工化 $65 ， 833$ (1962). 


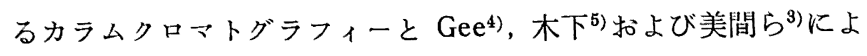
る薄層クロマトグラフィーが発表されているが，クロマトグラフ ィーでは多量の溶媒を必要とし，1回の操作で処理しうる試料の 量は限られている。著者らはモノェステル, ジェステル等の性質 を検討するため,できるだけ多量の試料をらる必要を感じ, 液一 液抽出法の検討を行なった。Snell ら6)はショ糖エステルの DMF 溶液からnーヘキサンにより脂肪酸メチルを抽出する方法を述べ ているが, シリカゲルカラムクロマトグラフィーによると, 上記 n一ヘキサン抽出物中には脂肪酸メチル以外, ショ糖ポリエステ ルがみとめられたが，一方ジェステル，特よびモノェステルはほ とんど存在しない。すなわち $n$-ヘキサン-DMF 系分配でポリエ ステルが分離されたことになる。著者らは DMF より更にポリエ ステル溶解性が低いと考えられるメタノールと $n$-ヘキサンその 他の非極性溶媒からなる系によって，モノェステルが分離しうる のではないかと考えて実験を行なった。

\section{2 実験}

\section{$2 \cdot 1$ 分析法}

（1）全ショ糖分 極性層フラクションはエタノールにて，ま た非極性層フラクションはクロロホルムにて希釈して一定量をと り溶媒除去後, Weis ら7)によるントロン硫酸法にて比色した。 ショ糖エステルに対する適用は別報1)に記したので省略する。

（2）エステル型脂肪酸 極性層フラクションはエタノールに て，また非極性層フラクションはクロロホルムにて希釈して一定 量をとり，溶媒を完全に除去してヒドロキサム酸鉄塩法にて比色 した ${ }^{8)}$ 。ショ糖エステルに対する適用は別報1)に記した。

（3） 分別物のカラムクロマトグラフ 詳細は別報1)に記した ので概要のみ記す。 $105^{\circ} \mathrm{C}$ にて 8 時間乾燥した関東化学製クロマ トグラフ用シリカゲル $(100 \sim 170$ メッシュ）6g をカラム（内径 $10 \mathrm{~mm}$, 筒長 $220 \sim 230 \mathrm{~mm}$ ) につめる。 $5 \%$ クロロホルム溶液と して試料 25〜 $50 \mathrm{mg}$ をカラムに添加して，室温にてクロロホル ム, クロロホルムーメタノール混液, および DMF にて溶出を行 ない, 全ショ糖分をアントロン硫酸法にて，またエステル型脂肪 酸をヒドロキサム酸鉄塩法で定量した。

\section{$2 \cdot 2$ 予備試験}

（1）ショ糖パルミテートの分別 試料（ショ糖エステル分約 92\%，カラムクロマトグラフィー1）によるモノェステル 分約 51 $\%, \mathrm{~F} / \mathrm{S} ※ 21.45) 5 \mathrm{~g}$ をメタノールー水混液 (9:1vol/vol) $100 \mathrm{ml}$ に加温懸濁（約 $50^{\circ} \mathrm{C}$ ) して, nーヘキサン, および表 1 に記した nーヘキサンークロロホルム混液各 $100 \mathrm{ml}$ にて計 4 回, $50^{\circ} \mathrm{C}$ に保 持して抽出した。表 1 は各フラクションの固型物（蒸発残留物） および F/S である。固型物の大部分は第 1 回抽出液とメタノ一 ルー水層にあつまり, メタノールー水層の $\mathrm{F} / \mathrm{S}$ は 1 に近くモノエ ステルの分離がほぼ行なわれたものと考えられ，試料中のモノェ

4) M. Gee, J. Chromatog. 9, 278 (1962).

5) 木下, 工化 66, 450, 455 (1963).

6) F. D. Snell, W. C. York, A. Finchler, Ind. Eng. Chem. 48, 1459 (1956).

7) C. S. Wise, R. Dimler, H. A. Davis, C. E. Rist, Anal. Chem. 27, 33 (1955).

8）関根，笹川，森田，大村，倉富編，“生化学領域に扣ける 光電比色法”各論 II, 南江堂 (1958), p. 114 .

\%2 $\mathrm{F} / \mathrm{S} ; \because ョ$ 糖エステル型脂肪酸 (モル)/エステル型ショ糖 (モル)
表 1 ショ糖パルミテート分別予備試験に括ける 各フラクションの固型物と $\mathrm{F} / \mathrm{S}$

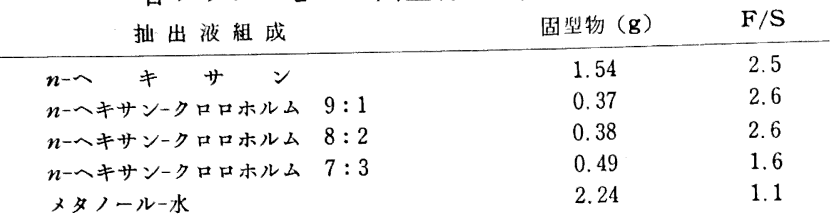

ステル推定量 $(2.35 \mathrm{~g})$ とメタノールー水層の固型物 $(2.24 \mathrm{~g})$ は ほぼ一致するので，モノェステルは非極性層へほとんど移行しな かったものと考劣られる。抽出回数に応じて抽出溶媒のクロロホ ルム含量をまして行くことによりトリェステル，ジェステル等の 分別抽出が行なわれるのではないかと考兵たが，第 1 回より第 3 回までの抽出液の $\mathrm{F} / \mathrm{S}$ はほぼ等しいのでジ以上のポリェステル は分離せずに抽出されるものと考えられる。

次に実際に分別物をらるため，上記試料 $50 \mathrm{~g}$ を用いて，ほほ 同様の抽出操作を行ない, メタノール-水層を乾固してカラムク ロマトグラフィー1)を行なったところ，モノ：ジ：ポリエステ ル； 89.6:9.6:0.7 となりモノェステルの分離が不完全ながら 行なわれた。

（2）ショ糖モノステアレートの分別 試料（ショ糖エステル 分 $89 \%$, カラムクロマトグラフィー1)によるモノェステル分 56 \%) $50 \mathrm{~g}$ をメタノール-水 $9: 1$ ( vol $/ \mathrm{vol})$ 混液 $500 \mathrm{ml}$ に懸濁し て、 $50^{\circ} \mathrm{C}$ に拈いて $n$-ヘキサン各 $500 \mathrm{ml}$ にて 3 回, $n$-ヘキサン一 クロロホルム $8: 2 \mathrm{vol} / \mathrm{vol}$ 混液各 $500 \mathrm{~m} l$ にて 3 回抽出後メタノ ールー水層を濃縮乾固してえた固型物 $18.5 \mathrm{~g}$ を, メチルエチル ケトン $100 \mathrm{~m} l$ により再沈股して $\left(50^{\circ} \mathrm{C} \rightarrow 20^{\circ} \mathrm{C}\right)$, 固型物 $16.6 \mathrm{~g}$ をえた。カラムクロマトグラフィーによりモノ：ジ：ポリエステ ル; $98.6: 0.8: 0.6$, 試料中の遊離ショ糖 $5.6 \%$, となり脂肪酸 メチルは上記クロマトグラフィーに打いてはみとめられなかっ た。しかしモノェステルの収率はクロマトグラフィーによる計算 值 $24.9 \mathrm{~g}$ の $74 \%$ 以下で低く, 約 7 $10 \mathrm{~g}$ (約 30 40\%)のモノエ ステルが非極性層に移行したものと推定される。

以上の予備試験の結果，パルミテートでは非極性層へのモノエ ステルの移行がほとんどなかったが，ステアレートではみとめら れたので，構成脂肪酸の種類により適当な溶媒系を探索する必要 がある。各種溶媒系を探索してモノェステルとジ以上のポリエス テルの相互分離を完全にするため, 少段数向流分配方式による試 験を行なった。

\section{$2 \cdot 3$ 少段数向流分配試験}

$2 \cdot 3 \cdot 1$ 供試試料 試料はラウレート, ミリステート, パルミ テートの 3 種であり，その成分組成を表 2 に示した。

表 2 少段数向流分配試験の供試試料

\begin{tabular}{|c|c|c|c|}
\hline 分析項目 供試試料 & ラウレート & ミリステート & パルミテート \\
\hline 脂肪酸純度 $\left.(\% / \text { 全酸 })^{\mathrm{a}}\right)$ & $\mathrm{C}_{12} ; 95.6$ & $\mathrm{C}_{14} ; 93.1$ & $\mathrm{C}_{1 \mathrm{e}} ; 97$ \\
\hline 平均分子量 ${ }^{b)}$ & 201 & 228 & 260 \\
\hline ショ枮エステル（\%） & 93.4 & 90.2 & 92.3 \\
\hline 遊離シ $=$ 糖 $(\%)^{\mathrm{c})}$ & 0.80 & 0.55 & 0.61 \\
\hline 脂肪酸メチル $\left.(\%)^{c}\right)$ & 1.36 & 5.23 & 2.91 \\
\hline 脂肪酸カリウム $(\%) \mathrm{d})$ & 1.08 & 0.50 & 0.10 \\
\hline
\end{tabular}

モノ: : : ポリ $(\mathrm{w} / \mathrm{w})^{\mathrm{c})} \quad 69.5: 20.7: 9.8 \quad 65.6: 21.7: 12.6 \quad 55.3: 29.5: 15.1$ a) ガスクロマトグラフィー（装置；岛津 GC-1 B，カラム；High Vacuum Silicon Greace (Dow Corning Co.)-Celite 22, 6mm $\phi \times 2.25 \mathrm{~m}$, カ

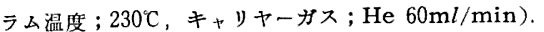

b)“食品添加物公定詣（普及版），日本食品衛生協会 (1960), p. 114. c) カラムクロマトグラフィー (2.1(3))

d) "Sucrose Ester Surfactants Research Report", Sugar Research Foundation Inc. October (1961), p. 66. 
$2 \cdot 3 \cdot 2$ 向流分配方式 $n$-ヘキサン $\left(68 \sim 70^{\circ} \mathrm{C}\right.$ 留分), トリクレ ン,メタノール，括よび水を種々の比で混合分液して扰き，等量 の極性層溶媒（メタノール扰よび水を主体とする層）を平衡管 0 〜4 となづけるフラスコに分注する。極性層溶媒と等量の非極性 層溶媒，扣上び試料を平衡管 0 に添加し， $40^{\circ} \mathrm{C}$ 飞加温，振々 5 して分液漏斗飞移して $40^{\circ} \mathrm{C}$ 亿保ちながら 10 分放置後, 分液し て極性層を管 0 にもどし非極性層は管 1 亿送る。以下上層が非極 性層の場合は上層完全除去型分配 33 の方式に従って分配移行を 行なら。二層の混合拉よび分液操作を通じて系の温度は $40^{\circ} \mathrm{C}$ 保つ。上層が極性層の場合は下層を移行させ，非極性層を完全に 分離する。分離された非極性層は慣習に従って分割 $\rho_{0} \sim \rho_{4}$ とな づけ，平衡管に残った極性層溶媒俚管の番号に対応して分割 $r_{0}$ $\sim r_{4}$ となづける。

$2 \cdot 3 \cdot 3$ 溶媒亲の比較検討 表 2 亿記 したショ糖ラウレート， 扣よびパルミテートにつき，それぞれ 3 種の溶媒系により，平衡 管数 5 本, 全溶媒量 $5 l$, 試料 $50 \mathrm{~g}$, 温度 $40^{\circ} \mathrm{C}$ の完全除去型向流 分配を行なった。いずれも極性層を固定層とした。純物質が得ら れていないので, 分配係数等の決定は行なわず，試料中に含まれ るジ以上のポリエステル量に対する非極性層固型物の百分率 (単 に移行率とする)をむって比較の対象とした。

\section{$2 \cdot 3 \cdot 3 \cdot 1$ ラウレート}

表 3 ショ糖ラウレートの向流分配における溶媒混合比 と移行蜜の関係

武験記号沜サン:トリクレン：メタノール：水移行率（\%)

$\begin{array}{llllllll}\text { L-1 } & 9 & : & 0 & : & 9 & : & 0\end{array}$

$\begin{array}{llllllll}\mathrm{L}-2 & 8 & : & 2 & : & 8 & : 2 & 10 \\ \mathrm{~L}-3 & 2 & : & 8 & : & 8 & : 2 & 57\end{array}$

移行率はトリクレン含量をますことにより高まり，分割 $r_{0}$ お よび $r_{1}$ では $\mathrm{F} / \mathrm{S}$ が 1 に近く，ジ以上の ポリェステルは極性層の 後半に移行しているものと推定される。㘠 1 は各溶媒系による分 配曲線を糖の分布によりあらわしたものである。方式 L-3※4を 2 回くりかえして試料 $100 \mathrm{~g}$ を処理し, 分割 $r_{0}$ の溶媒を除去して 固型物 $54 \mathrm{~g}$ をえ（粗モノラウレートと称する）, カラムクロマト グラフィーその他により分析した結果，モノ：ジ: ポリ (w/w); $96.9: 2.1: 0.9$, 遊離ショ糖 (\%/試料)；9.7, 脂肪酸カリウム

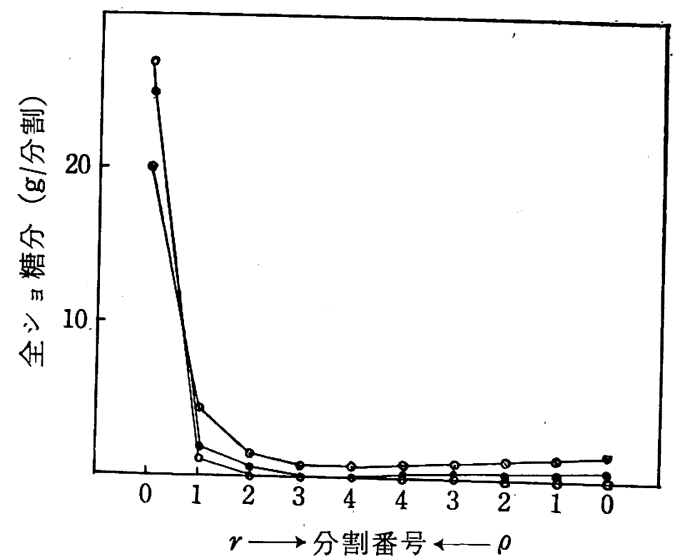

図 1 各種溶媒系によるショ糖ラウレートの向流分配曲線 一 $\mathrm{O}-\mathrm{L}-1,-\longrightarrow \mathrm{L}-2,-\mathrm{O}-\mathrm{L}-3$ (表 3参照)

※3 E. Hecker, 次田皓, 沢田文夫訳, “カゥンターカレント” (1958) 南江堂 の訳語に従った.

$※ 4$ 試験記号 L-3 の溶媒を用い, 平衡管数 5 本, 全溶媒量 $5 l$, 試料 $50 \mathrm{~g}$, 温度 $40^{\circ} \mathrm{C}$ の完全除去型分配を方式 L-3 と称す る.
(\%/試料)；1.6, 脂肪酸メチル (\%/試料)；1.0 となり, 非ショ糖 エステル性の不純物は多いが, ショ糖エステル中のモノェステル 含量は比較的高いものがえられた。

$$
2 \cdot 3 \cdot 3 \cdot 2 \text { パルミテート }
$$

表 4 ショ糖パルミテートの向流分配における溶 媒混合比と移行率の関係

\begin{tabular}{|c|c|c|c|c|c|c|c|}
\hline 武跧䟕号 & $n$ ーヘキ+ & : . & $\eta \nu$ & : & メタノー & : 水 & 移行率 (\%) \\
\hline p-1 & 10 & $:$ & 0 & : & 9 & $: 1$ & 21 \\
\hline $\mathrm{p}-2$ & 8 & $:$ & 2 & : & 8 & $: 2$ & 74 \\
\hline $\mathrm{p}-3$ & 5 & $:$ & 5 & : & 8 & $: 2$ & 94 \\
\hline
\end{tabular}

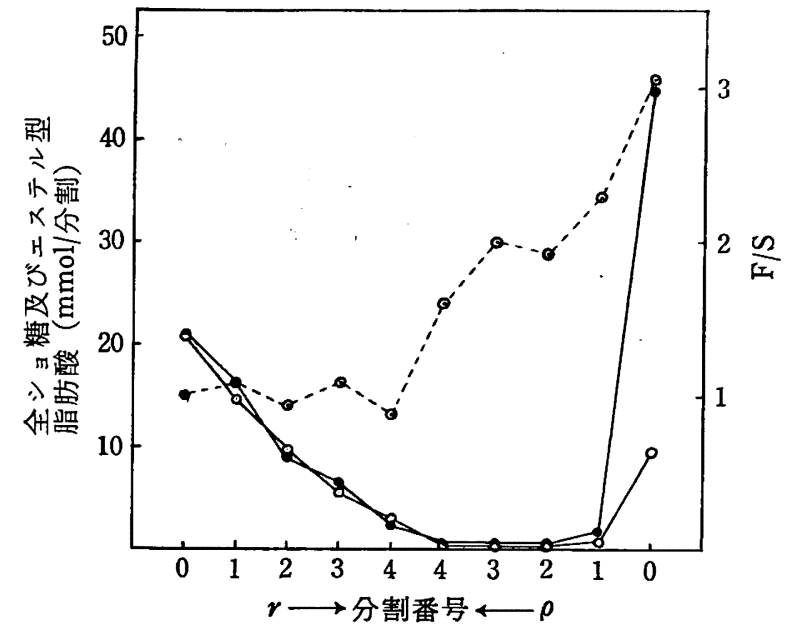

図 2 方式 p-2によるショ糖パルミテートの向流分配曲線

-———ステル型脂肪酸, 一O- 全ショ糖, - - - - - - F/S

パルミテートに拈いても，含水量拉よびトリクレン量をまして いくと分離は良好になる。図 2 は方式 $\mathrm{p}-2$ による分配曲線の詳 細である。方式 $\mathrm{p}-2$ を 5 回くりかえして試料 $250 \mathrm{~g}$ を処理して, 分割 $r_{0} \sim r_{2}$ の溶媒を除去して粗モノパルミテート $110 \mathrm{~g}$ をえた。

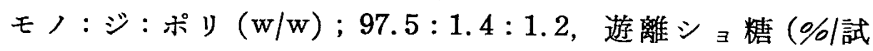
料)；3.9, 脂肪酸カリウム ( $\% /$ 試料 $), 1.5$, 脂肪酸メチル $(\% / \%$ 料), 11.9 となり, 非ショ糖エステル性不純物の含量は高いが, シ ヨ糖エステルに対するモノェステルの比率は高い。

$2 \cdot 3 \cdot 3 \cdot 3$ ミリステート ラウレート执よびパルミテートの場 合から推定して, n-ヘキサンートリクレンーメタノール-水, 2 : $8: 8: 2$ の溶媒系 $10 l$ を用いて, 試料 $200 \mathrm{~g}$ を 2.3.3に記した方 式による完全除去型分配にかけ，極性層分割 $\boldsymbol{r}_{0} \sim \boldsymbol{r}_{2}$ より固型物 $132 \mathrm{~g}$ をえ, 後述の精製を行なって固型物 $100 \mathrm{~g}$ をえた。精製モ ノミリステートのモノ：ジ：ポリェステルは 93.6:5.2:1.2 と なり，不十分であるが一応分離が行なわれた。

\section{$2 \cdot 4$ 粗モノェステルの精製と精製エステルの性状}

液一液抽出法によってえた粗モノェステルはショ糖エステル以 外の不純物を含むので，下記に従って精製を行なった。

$2 \cdot 4 \cdot 1$ ラウレート 粗モノラウレート $72 \mathrm{~g}$ を $n$-ブタノール 一水 $1: 1 \mathrm{vol} / \mathrm{vol}$ 混液全量 $4 l$, 平衡管 3 本の完全除去型分配にか け，有機層分割 $r_{0}$ より固型物 $55 \mathrm{~g}$ をえ，アセトンーn-ヘキサン $1: 1(\mathrm{vol} / \mathrm{vol})$ 混夜 $300 \mathrm{ml}$ により 2 回再沈殿を行ない $\left(50^{\circ} \mathrm{C} \rightarrow\right.$ $\left.2^{\circ} \mathrm{C}\right)$, 固型物 $40 \mathrm{~g}$ をえた。

$2 \cdot 4 \cdot 2$ ミリステート 粗モノミリステート $132 \mathrm{~g}$ を $\mathrm{sec}$-ブタ ノールークロロホルムー水, $1: 1: 2(\mathrm{vol} / \mathrm{vol})$ 混液全量 $4 l$ にて 平衡管 3 本の完全除去型分配にかけ，有機層分割 $r_{0}$ よりえた固 型物 $110 \mathrm{~g}$ をメチルェチルケトンーnーヘキサン 1:1 ( vol/vol) 混 液 $750 \mathrm{ml}$ より 2 回再沈股を行ない $\left(50^{\circ} \mathrm{C} \rightarrow 2^{\circ} \mathrm{C}\right)$ 固型物 $100 \mathrm{~g}$ を 
えた。

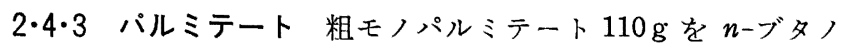
一ル-水 $1: 1(\mathrm{vol} / \mathrm{vol})$ 混液 $3.6 l$ 亿て平衡管 3 本の完全除去型 分配にかけ，有機層分割 $r_{0}$ を乾固して，メチルェチルケトン一 $n$-ヘキサン $1: 1(\mathrm{vol} / \mathrm{vol})$ 混夜 $200 \mathrm{~m} l$ にて 2 回再沈殿を行ない $\left(50^{\circ} \mathrm{C} \rightarrow 2^{\circ} \mathrm{C}\right)$, 固型物 $82 \mathrm{~g}$ を学た。

以上の他 $2 \cdot 2 \cdot 2$ 亿記したステアレートを加兄，成分組成を表 5 に一括した。分析法は表 2 に注記したものと同様である。

表 5 各種精製エステルの成分組成

\begin{tabular}{|c|c|c|c|c|}
\hline & ラウレート & ミリステート & パルミテート & ステアレート \\
\hline 脂肪酸純度 & $\mathrm{C}_{12} ; 95.6$ & $\mathrm{C}_{14} ; 93.1$ & $\mathrm{C}_{18} ; 97$ & $\mathrm{C}_{18} ; 99.3$ \\
\hline 平均分子量 & 201 & 228 & 260 & 285 \\
\hline 遊雄ショ榶（\%) & 0.8 & 0.8 & 1.1 & 5.6 \\
\hline 脂肪酸メチル（\%） & こん跡 & こん跡 & こん跡 & こん跡 \\
\hline 脂肪酸カリウム（\%) & 1.5 & こん跡 & こん跡 & 0.5 \\
\hline
\end{tabular}

モノ:シシ:ポリ(w/w)* 96.1:1.4:1.7 93.6:5.2:1.2 $\quad 98.3: 0.8: 0.8 \quad 98.6: 0.6: 0.8$

*この項は試料中のショ棌エステルを 100 とした時の比であるか，モノェステルは な拉数個の異性体の混合物と考えられる。

図 3 护よび図 4 は精製 表 6 各種精製エステルの軟化点 パルミテート拈よび出発 試料としたモノエステル 含量 $51 \%$ のパルミテー トのカラムクロマトグラ ムである。

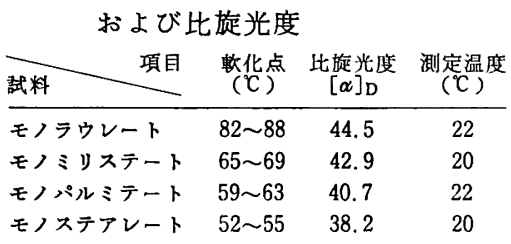

各種精製エステルの純度は一様でないが, 比較のため, 軟化点 および比旋光度を測定した。試料は表 5 のものと同一であり，比 旋光度は $4 \%$ エタノール溶液として測定した。

各試料の純度招よび比旋光度測定温度が一定でないので, 笡密 な比較はできないが, 軟化点, 比旋光度とも構成脂肪酸炭素数の 增加従って低下寸るものと考兄られる。

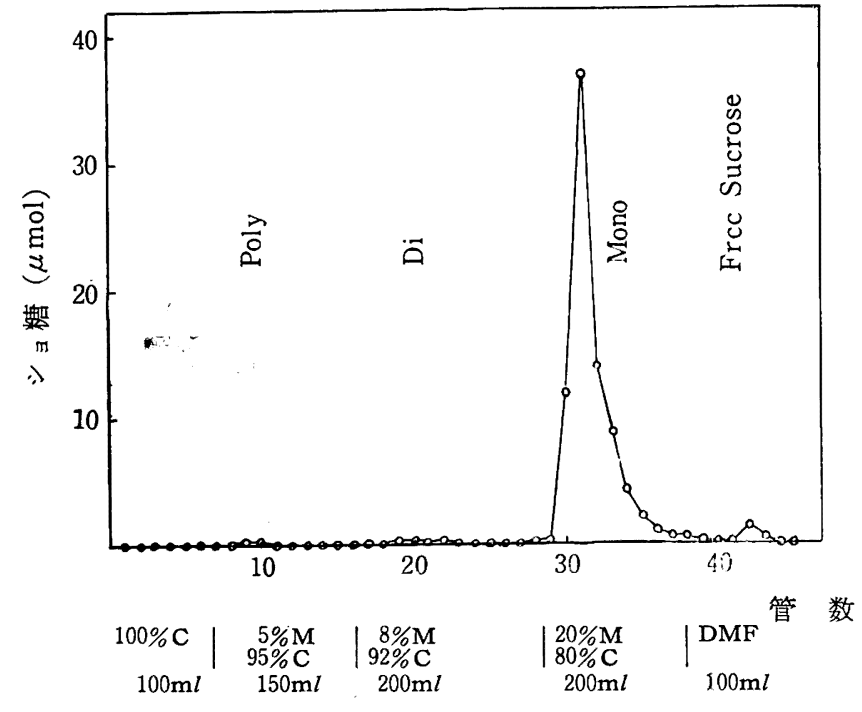

図 3 精製パルミテートのクロマトグラム (シリカゲルカラム)

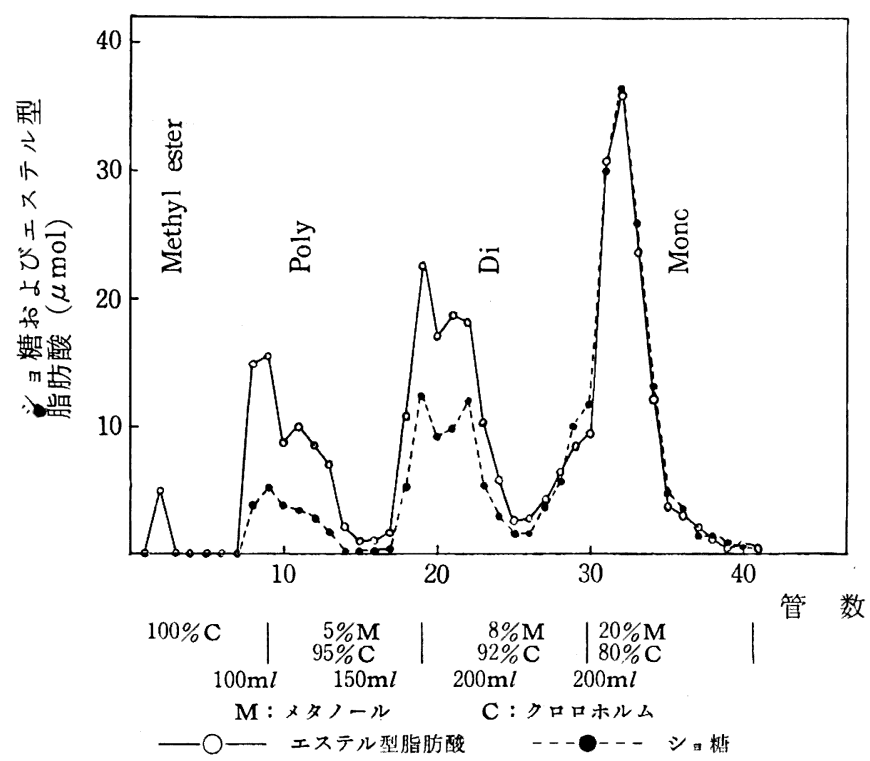

図 4 分別試験の出発試料としたショ糖パルミテートの クロマトグラム（シリカゲルカラム）

\section{3 考察}

一般に上記の溶媒系を用いた液-液抽出法によるモノェステル の分離に扔いては構成脂肪酸の種類によって適当な溶媒混合比を 壳らばねばならないが，多段向流分配法を用いれば溶媒系を固定 しても，比較的広範囲の脂肪酸からなるモノェステルを分離でき るのではないかと考兄られる。本操作でショ糖エステル混合物は モノェステルとジ以上のポリエステルに分離されるが, 両フラク ションとも単一物質ではないので, 分配係数の決定は行なってい ない。上述の向流分配によりえられた粗モノェステルは通常使用 したメタノールと加温することによりメタノリシスを伴って遊離 ショ桾および脂肪酸メチルを含有するので更に精製を必要とし た。精製エステルの軟化点扣よび比旋光度は脂肪酸炭素数の增加 に従って低下寸るが, Osipow ら9) も軟化点について著者らと同 様の関係をえているが, 比旋光度では炭素数との関係が不規則で ある。ラウレートの軟化点は彼らの得た值の方がむしろ高い。美 間ら ${ }^{10}$ による比旋光度測定値は著者らの場合同様, 炭素数との関 係は規則的であったが，パルミテート拉よびステアレートの比旋 光度はやや低い。

(1963 年 4 月 1 日, 日本化学会第 16 年会一部講演)

おわりに本研究の発表を許可された副社長橋本德二，始終こ指 導を賜わった研究所長 久野秀夫, 陚料の調幣, ガスクロマトグ ラフィーにあたられた研究所員藤山康, 実験に協力された西 博昭の各位に感謝いたします。

9) L. Osipow et al, Ind. Eng. Chem. 48, 1459 (1956).

10）美間ら, 薬誌 78, 988 (1958). 